\title{
THE EFFECTIVENESS OF ADOBE FLASH VIDEO GAMES TO ENHANCE VOCABULARY COMPREHENSION OF THE SECOND GRADE STUDENTS AT SMPN 2 TAKALAR
}

\author{
Patur Rahman \\ Kamsinah \\ Erwin Hafid \\ Islamic Education Department \\ fr22694@gmail.com \\ k_inauin@yahoo.co.id \\ erwinhaf@gmail.com
}

\begin{abstract}
The target of this research was to determine the effect of Adobe Flash Videogames to enhance students' vocabulary comprehension. Therefore, the principle problem was only one, that was to what extent was Adobe Flash Video Games effective to enhance vocabulary comprehension of the second grade students of SMPN 2 Takalar. The study was using quasi Experimental Design, exactly "Non-equivalent Control Group Design. The study involved 60 students, second grade students in SMPN 2 Takalar. This research employed quasiexperimental design with two group pre-test and post-test design. There were two variables in this study; they were independent variable (the use of adobe flash video games) and dependent variable (the vocabulary comprehension of the students). The population of this research was the second grade students at SMPN 2 Takalar which consisted by 336 students. The sample of the research consisted of 60 students which was taken by using purposive sampling technique, 30 students were taken as experimental class and 30 students as control class. The instrument of this research was a written vocabulary used in the pre-test and post-test. The treatment was given by using adobe flash video games. The result of the data of the research indicated that there was a significant difference between the students' post-test in experimental class and control class. The mean score of the post-test (80.85) in experimental class was greater than the mean score of the post-test (38.61) in control class. The standard deviation of the post-test (43.27) in experimental class was higher than the standard deviation of the post-test in control class (10.94). From the t-test, the researcher found that the value of the t-test (5.10) was higher than the t-table (2.042) at the level of significance 0.05 with degree of freedom (df) $=58$. Based on the finding and discussion of the research, the researcher drawn a conclusion that the use of Adobe Flash Video Games was effective to enhance the vocabulary comprehension of the second grade students at SMPN 2 Takalar.
\end{abstract}

Keywords: Adobe Flash video Games, Vocabulary Comprehension

\section{INTRODUCTION}

$\mathrm{N}$ owadays, English plays the role as a bridge in language and technology. As a bridge in language, English as a communicator of people around the world when go abroad.

It is really essential for global requirements. In technology, English is needed for getting a further comprehension of technology to understand many specification of it. Specifically, the technology such video games generally are using English and the video 
games are being used not only in entertainment but also in Education, especially English to be learnt and taught. The power of gamification has widely acknowledged in education to engage and motivate learners when used properly in classrooms (Lee, \& Hammer, 2011: 91).

Furthermore, learn English words and their meanings, the most important to be concerned is how the words related one another in English sentence. It concludes that in teaching vocabulary is not only give the meaning of the word but also teach how the word worked in sentence, because there are many words which have more than one meaning.

There is a basic part in English. Vocabulary, one of English components or sub skills that must be taught to the learners' and vocabulary has the primary role for all languages. Moreover, some researchers regarded that vocabulary is more important than grammar which underlined "no matter how well the students learns grammar" other words the first that to be mastered for language learnerin learning language especially English is vocabulary.

In other chase, students and teachers are forced to deal with AEC (ASEAN Economic Community). In 2015, AEC has been established which mean that every job opportunity is able to get not only for Indonesian but also the foreigners have the opportunity to set a job in Indonesia. In Science and Technology, AEC Blueprint: 29 underlined that Realized ASEAN's intent to sustain its economic growth and to remain globally competitive will be supported by appropriate science, technology and innovation (STI) applications. Therefore, every single person in Indonesia should be employed some skills to deal with it especially in education technology that would be used by teachers and students.

The problem in learning and teaching English still exists at school. The students usually forget the meaning of the words which have been taught or practiced before. At many chases, most of students unable to state theirideas and opinion well since there are not accustomed to speak, feel shy, hesitated and fear to make a mistake. Commonly, it caused by limited vocabulary.

Usually vocabulary is being taught through memorizing words or drillings patterns. For teacher, creating English teaching effectively and efficiently is not an easy job, therefore, that the English teacher must be able to organize teaching and learning activities. In reality of learning English, memorizing vocabulary is boring for some students. The technique which used in teaching vocabularies is monotonous.

Those chases supported by the observation result which was conducted by the researchers. The main problem of the students to learn English is the lack of vocabulary, they were boring to memorize many words in the conventional method such as drilling or repetition to pronouce the words. The result was taken by quick questions in every class about their main problem in English, and the result was totally same.

Not only students but also English teacher was asked about their problem to teach. The teacher felt confused to teach vocabulary because they have no idea about a sophisticated method and they was using traditional method as a primary way to teach 
vocabulary and it made the students bored.

Based on the problems above, the researcher wanted to take one of the teaching strategies that will be able to motivate the students to learn English and improve the teaching skill to deal with AEC (ASEAN Economic Community). But in this research, the researcher will focus on the strategy to overcome the learning vocabulary obstacles, the strategy called Adobe Flash Video Games. It is a video game platform that operated in Adobe Flash Player software. It is a software maintained by Macromedia (now Adobe), one of the largest companies in the sector of multimedia and software for the web. This method was very enjoyable for the students to learn vocabulary and gave a dynamic teaching way for the teacher.

Based on the problem and wording above, the researcher focuses on The Effectiveness of Adobe Flash Video Games to Enhance Students' Vocabulary Comprehension at the Second Grade Students of SMPN 2 Takalar. The researcher has looked down on the field and saw that Adobe Flash Games was effective or not within enhancing vocabulary comprehension of the Students.

Based on the previous background of the problem, the researcher assumed that the difficulty in understanding English was because of the lack of vocabulary. So the researcher needed to know the using adobe flash video games by the following research questions: "Is the use of Adobe Flash Video Games effective to enhance the vocabulary comprehension of the second grade students at SMPN 2 Takalar?"

\section{REVIEW OF RELATED LITERATURE}

There were some researchers that had underlined the similar method. Sze Lui (2002: 91 ), investigated video games to help students learn vocabulary in a tertiary institution in Macau. The results showed that students preferred using technology to learn vocabulary not only because of it was more fun and exciting but also because the technology facilitated vocabulary retention. Gamification improved students' attitudes towards language learning. It will be able to be a medium to motivate students in learning especially to learn vocabulary.

Gamification is a sophisticated way to learn and can be motivation to learn further because motivation is crucial in learning. If students are not motivated, even if they have the ability to solve a problem, they may not end up solving it. Conversely, if they are highly motivated, even though they have limited ability, motivation will help them to find the means to accomplish a task and eventually enhance the ability. However, according to Sze Lui (2002: 91), motivation and ability alone are not enough; a 'trigger', which is like a call for action, is also required so as to tell the user to achieve a certain behavior. Software applications can serve as such 'trigger' to change people's attitudes and behavior. 
Patur Rahman, Kamsinah \& Erwin Hafid, The Effectiviness of Adobe Flash Video Games...

Games have also been shown to help learners learn better when they are participating and having fun. The colorful and interactive online games attract players because they can stimulate more than one sense at a time.

Lee \& Hammer (2011: 4) pointed out in their study that educational games are able to meet three types of learners' intellectual needs (namely, cognitive, emotional and social needs), thus creating positive emotional experiences. Cognitive benefits include the development of problem-solving skills. Players must successfully complete one level before moving on to the next level. The rewards obtained for each level provide constant motivation and also develop players' skills at the same time. Gamification can also address students' emotional needs. In order to win, players must experience numerous failures, and each time they fail they learn something. The satisfaction of completing a level and advancing to the higher level offsets the negative feelings of repeated failures. Moreover, the immediate feedback provided about players' performance can be motivating and encouraging and through repeated attempts, results a re improved. Students learn that making mistakes or even failure is not the end but provides an opportunity to learn and improve their skills and knowledge. However, if students experience failure in a traditional classroom, it is difficult to turn this negative emotion into a positive one. Gamification does offer the opportunity to turn negative emotions into positive experience.

Rezvan Saffarian \& Gorjian, (2012: 44) investigated the role of computer-based video games on facilitating children's cognitive learning. Their study investigated the effect of the varied types of instructional delivery strategies on children's learning achievement. The subjects of their study comprised of 418 EFL teachers and learners dealing with EFL in Iranian institute. The students' receive two different instructional treatments: (1) traditional computer-assisted instruction (CAI) programs; and (2) a computer-based video game. The results of their research revealed that "the experimental group who used computer games outperformed the control group who did not use it as a teaching aid in foreign language classroom In other words computer games exchanges can play a facilitative role in teaching and learning second language".

Ghosoon (2012:5) in his thesis underlined that significant difference in the fifth graders' achievement of English language faced to the method in purpose of using educational computer games strategy. It means that, computer games in education were shown magnification of the students achievement.

Based on those findings, the research recommended the essentiality of applying an educational computer games strategy in teaching English language to bring about better outcomes in students' achievement of English language.

Richard Stanford and friends (2006: 4) explained "games may have potential to support learning and while many teachers and pupils expressed enthusiasmin using games in lessons. 
It was really support the purpose of this research to increase the enthusiasm to learn by using games in lesson.

Mark Griffith (2002: 47) had shown in his journal "Videogames have great positive potential in addition to their entertainment value and there has been considerable success when games are designed to address a specific problem or to teach a certain skill”. It means that Video games were recommended in entertaining and skill improvement for the researcherin his experiment.

David Brett (2005: 1) explained in his journal "the almost unlimited possibilities of Flash may come to the rescue. Being a program that is essentially for the creation of animations, dynamic examples can be programmed to run at the start of each exercise, or in the first exercise in a series of similar types, providing a foolproof illustration of the requirements of the task".

According to the references above, The researcher stated that learning by using video games in other word gamification is an essential improvement in educational world. Teaching by using video games especially adobe flash is really helpful to improve English in some aspects such as improving vocabulary, energizing the mood of the students, entertaining, and giving some variety creations for teachers to design their teaching media. The researcher tried to apply the way by using adobe flash video games to determine the effectiveness of it in SMPN 2 Takalar.

\section{RESEARCH METHOD}

The design of the research conducted by using quasi-experimental design, especially non-equivalent control group design. This method used purposive sampling that the sample would be chosen. In this method, there were two classes, which were experimental class and controlled class. In the experimental class, Adobe Flash Video Games was conducted as well as pretest and posttest and the controlled class only got pretest and posttest. This method was appropriate in the research because it described whether Adobe Flash Video Game was effective or not.

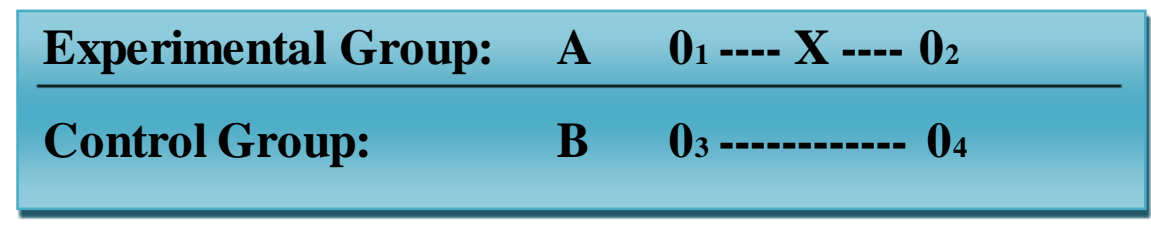

Figure 3.1 Experimental Design (Creswell, 2014: 242)

Sample is partially or the representative of the population studied (Arikunto, 2013: 174). In this research, the sample was two classes. Technique of sampling that used in this research was purposive sampling. Arikunto (2013) stated that purposive sampling technique chosen because of several aims. In accordance with Arikunto (2013) stated that purposive sampling technique is chosen by several decisions. The reason why the researcher chose 
Patur Rahman, Kamsinah \& Erwin Hafid, The Effectiviness of Adobe Flash Video Games...

purposive sampling because of the teacher's suggestion which related to the electricity of the classrooms. The researcher chose all of the students in two classes as sample and the number of students was 60 in two classes.

The instrument that was used to collect data of this research was achievement test. The achievement test which consisted of 35 numbers of short answer where 10 items using pictures and the others are not visualized with pictures. According to www.studygs.net/tsttak5.htm., short answer is a test to measure whether the students have a foundation or primary knowledge about a topic. Usually factual and based from the keyword or vocabulary.

\section{FINDINGS AND DISCUSSION}

\section{A. Findings}

The findings of the research were based on the results of the data analysis. The data analysis was used to collect data. The vocabulary test consists of pre-test and post-test. The pre-test was given to find out the initial students' vocabulary before presenting teaching by using adobe flash video games, and the post-test was given to find out the improvement of the students' vocabulary after giving the treatment.

\section{The Classification of Students' Pre-test in Experimental Class and Control Class}

The following table shows the distribution of frequency and percentage of final score of students' vocabulary at second grade students in SMPN 2 Takalar, in pre-test in experimental and control class.

Table 1 The Distribution of Score and Frequency of Experimental Class Score in Pre-test

\begin{tabular}{|c|c|c|c|}
\hline No. & Classification & Score & Frequency \\
\hline 1. & Excellent & $95-100$ & 1 \\
\hline 2. & Very Good & $85-94$ & 0 \\
\hline 3 & Good & $75-84$ & 0 \\
\hline 4. & Fairly good & $65-74$ & 2 \\
\hline 5. & Fair & $55-64$ & 2 \\
\hline 6. & Poor & $45-54$ & 18 \\
\hline 7. & Very Poor & $0-44$ & $\mathbf{3 0}$ \\
\hline \multicolumn{2}{|c|}{ Total } & \\
\hline
\end{tabular}

Table 1 above shows the rate percentage of score of experimental class in pre-test from 30 students, there was only 1 student who got excellent score. None students in very good and good criteria. There were 2 students got fairly good and 2 in fair score, 7 students got poor score, and 18 student acquired very poor score. 
Table 2 The Distribution of Score and Frequency OfControl Class Score in Pre-test

\begin{tabular}{|c|c|c|c|}
\hline No. & Classification & Score & Frequency \\
\hline 1. & Excellent & $95-100$ & 0 \\
\hline 2. & Very Good & $85-94$ & 0 \\
\hline 3 & Good & $75-84$ & 0 \\
\hline 4. & Fairly good & $65-74$ & 0 \\
\hline 5. & Fair & $55-64$ & 1 \\
\hline 6. & Poor & $45-54$ & 29 \\
\hline 7. & Very Poor & $0-44$ & $\mathbf{3 0}$ \\
\hline \multicolumn{2}{|c|}{ Total } \\
\hline
\end{tabular}

Table 2 shows the rate percentage of score of control class in pre-test from 30 students, none students who got excellent until fair score, 1 student got poor score, and 29 aquired very poor score.

\section{The Classification of Students' Post-test Scores in Experiment and Control Class}

The following table shows the distribution of frequency and percentage of final score of vocabulary comprehension of the students in 2nd grade at SMPN 2 Takalar in post-test in experimental and control class.

Table 3 The Distribution of Frequency and Percentage of

Experimental Class Score in Post-test

\begin{tabular}{|c|c|c|c|}
\hline No. & Classification & Score & Frequency \\
\hline 1. & Excellent & $95-100$ & 0 \\
\hline 2. & Very Good & $85-94$ & 14 \\
\hline 3 & Good & $75-84$ & 7 \\
\hline 4. & Fairly good & $65-74$ & 6 \\
\hline 5. & Fair & $55-64$ & 2 \\
\hline 6. & Poor & $45-54$ & 0 \\
\hline 7. & Very Poor & $0-44$ & $\mathbf{3 0}$ \\
\hline \multicolumn{2}{|c|}{ Total } & \\
\hline
\end{tabular}

While, the rate frequency of score of the experimental class in post-test from 30 students as table 3 above shows that there was no student got excellent score but it showed a change significantly in very good score which has been aquired by 14 students, 7 students got good score, 6 students got fairly good, 2 students aquired fair, and 1 student got poor. There was no students got very poor anymore after applied adobe flash video games.

Table 4 The Distribution of Frequency Percentage of Control Class Score in Post-test

\begin{tabular}{|c|c|c|c|}
\hline No. & Classification & Score & Frequency \\
\hline 1. & Excellent & $95-100$ & 0 \\
\hline 2. & Very Good & $85-94$ & 0 \\
\hline 3 & Good & $75-84$ & 0 \\
\hline
\end{tabular}


Patur Rahman, Kamsinah \& Erwin Hafid, The Effectiviness of Adobe Flash Video Games...

\begin{tabular}{|c|c|c|c|}
\hline 4. & Fairly good & $65-74$ & 1 \\
\hline 5. & Fair & $55-64$ & 2 \\
\hline 6. & Poor & $45-54$ & 4 \\
\hline 7. & Very Poor & $0-44$ & 23 \\
\hline \multicolumn{2}{|c|}{ Total } & $\mathbf{3 0}$ \\
\hline
\end{tabular}

While, the rate frequency of score of control class in post-test from 30 students as table 4 above shows that no one students got excellent, very good, and good score, 1 student got fairly good, 2 students got fair score, 4 students got poor and 23 others aquired very poor score.

Based on the table 3 and 4 , it can be concluded that the rate of frequency in post-test was higher than the rate of frequency in pre-test.

\section{The Mean Score and Standard Deviation of Experimental Class and Control Class}

After calculating the result of the students score, the mean score and standard deviation of both classes can be presented in the following table

Table 5 The Mean Score and Standard Deviation of Experimental Class and

Control Class in Post-test

\begin{tabular}{|c|c|c|}
\hline Class & Mean Score & Standard Deviation \\
\hline Experimental & 80,85 & 43,27 \\
\hline Control & 38,61 & 10,94 \\
\hline
\end{tabular}

The table above shows that, the mean score of experimental class in post-test was $(80,85)$ and the standard deviation of experimental class was $(43,27)$, while the mean score of control class in post-test was $(38,61)$ and its standard deviation was $(10,94)$. It means that, the mean score of control class was lower than mean score of experimental class.

The significant score between experimental and control class can be known by using t-test. The result of t-test can be seen in table 6 as follows:

Table 6 Distribution the Value of T-test and T-table in Post-test

\begin{tabular}{|c|c|c|}
\hline Variable & T-test Value & T-table Value \\
\hline Post-test & 5.10 & 2.042 \\
\hline
\end{tabular}

The table above shows that $\mathrm{t}$-test value was higher than $\mathrm{t}$-table. The result of the test shows there was a significant difference between $\mathrm{t}$-table and t-test $(2.042<5.10)$, it means that, t-table was lower than t-test.

The result of the t-test statistical analysis shows that there was a significant difference between the experimental class who got treatment by using Adobe Flash Video Games with control class that was got treatment by Conventional Method. The statement was proved by the t-test value (5.10) which is higher than $\mathrm{t}$-table value (2.042), at the level of significance 0.05 and the degree of freedom $\left(\mathrm{N}_{1}+\mathrm{N}_{2}\right)-2=(30+30)-2=58$. 


\section{Discussion}

Based on the percentage of score in experimental class in pre-test, Almost whole students got very low score that need an experiment of new way to enhance students' vocabulary comprehension. Adobe flash video games was applied and proved a signifcicance different after the researcer was doing a treatment, the score of students in experimental class increased significantly that the score of the students in the control class. The score has been attached previously and had been compared.

In the treatment, not only vocabluray that has been enhanced but also the emotional of the students was being under control to keep their mood in learning as the purpose of the method. In the same way, Lee \& Hammer (2011: 4) underlined that technology especially gaming brings up positive emotional feeling.

The main purpose is cognitive absolutely in vocabulary comprehension was successfully enhanced in experiment class by prove of the significance score of the control class. Based from the related findings, Rezvan Saffarian \& Gorjian, (2012: 44) underlined about it also.

It can be concluded that using Adobe Flash Video Games to enhance Students' vocabulary comprehension in Second grade of SMPN 2 Takalar was effective. There are several theories that support this method, Tze Lui said in his Journal that video games make the students motivated and feel excited to learn English because the technology has facilitated by vocabulary retention.

There were needed much control of the teacher about the usage of the method. Because technology especially in gaming usually make the students forget the main purpose of the method and focus in playing.

Although The result had shown a significant difference between control class and experimental class. Post test in experimental class indicated high score after the application of the adobe flash video games, but there are many things that must be prepared for teacher such as projector, electricity, and students mood.

However, there are many weaknesses of the research;

a. This method cannot be applied in school which no have electricity in the classes.

b. Inventory preparation such as projector and laptop have to prepare by the teacher because sometimes, the school has the elctricity but it does not have projector or laptop for each teachers.

c. If teacher unable to manage the game in right way, the students will play only without pay attention to the essence of the material that has been brought by the teacher.

\section{CONCLUSION AND SUGGESTION}

Based on the findings, there are two conclusions The use of Adobe Flash Video Games to enhance Students' Vocabulary Comprehension at The Second Grade Students in SMPN 
Patur Rahman, Kamsinah \& Erwin Hafid, The Effectiviness of Adobe Flash Video Games...

2 Takalar is effective. The total score of students in Experimental class in the post-test is 2425,55 and 1168,46 for Control class. In addition, the mean score in post-test for Experimental class is 80.85 and 38.61 for Control class. The data above shows that students' competence in Experimental class is higher than in Control class. The t-test for both classes in post-test is 5.10 compared to the t-table with 2.042 for $\alpha 0.05$ with degree of freedom ( $\mathrm{df}$ ) $=58$ since the score of $\mathrm{t}$-test is higher than the score of $\mathrm{t}$-table, alternative hypothesis $\left(\mathrm{H}_{1}\right)$ was accepted and null hypothesis $\left(\mathrm{H}_{0}\right)$ was rejected. It means that using adobe flash video games which was applied in the Experimental class is effective to enhance vocabulary comprehension. Students' score in the pre-test in Experimental class is lower than in the post-test. The use of the method was really brought up the positive emotional experience of those students. Not only the emotional but also the cognitive value had been enhance to make the students smarter.

In relation to the conclusion above, the researcher proposes the following offers:

1. Using adobe flash video games as an up to date method in general classroom for general age because beside social control, cognitive, and psychological, it can motivate the learners to be motivated also.

2. All Teachers should know how to use the adobeflash videogames to be an interesting teacher.

3. The game should be applied to University students to be more inovated students.

\section{REFERENCES}

Arikunto, Suharsimi. Prosedur Penelitian: Suatu Pendekatan Praktik. Edition. XV: Jakarta: Rineka Cipta, 2013.

AEC Blueprint. ASEANEconimic Community Blueprint. ASEAN Secretariat. Jakarta. 2015

Brett, David. Creating Interactive Material for Teaching Phonetics Using Macromedia Flash MX. University of Sassary, Italy. 2005

Creswell, John W. Educational Research: Planning, Conducting, and Evaluating Quantitative and Qualitative Research. Boston: Pearson. 2012.

Gay, etc. Educational Research: Competencies for Analysis and Applications. Edition. VIII: New Jersey: Pearson Education Inc, 2006.

Ghanbaran,Shamira-Ketabi Saeed.. Multimedia Games and Vocabulary Learning. Finland: Academy Publisher Manufacture. 2014.

Griffiths Mark. The educational benefits of videogames. Nottingham Trent University.2002 Harmer. The Practice of English Language. Longman. 2001

Hartoyo. Information and Communication Technology (ICT) in Language Learning. Semarang: Pelita Insani. 2012

Hornby. Oxford Advanced Learner's Dictionary of Current English. Oxford University Press, 1995. 
Lee, J. J., \& Hammer, J. Gamification in education: What, how, why bother?. Academic Exchange Quarterly, 15(2). 2011

Lui,Sze. Use of Gamification in Vocabulary Learning. Macau: University of Macau. 2013

Maizora, Syafdi. Pembuatan Media Pembelajaran Dengan Macromedia Fash 8. Accessed on July, 6th May 2016 from:

Qteefan Nafeth Ghosoon. The Effectiveness of Using Educational Computer Games on Developing Palestinian Fifth Graders' Achievement in English Language in Gaza Governorate. Islamic University of Gaza. 2012

Saffarian, Rezvan \& Gorjian, Bahman. Effect of computer-based video games for vocabulary acquisition among young children: An experimental study. United States : World Science Publisher.2012

Standford, Richard. Teaching with Games Using commercial off-the-shelf computer games in formal education. United Kingdom : Electronic Arts, Future Lab. 2006

Sugiyono, Metode Penelitian Pendidikan: Pendekatan Kuantitatif, Kualitatif, dan R\&D.Cet. X; Bandung: Alfabeta, 2010.

Yudhiantoro, Dhani. Membuat Animasi Web dengan Macromedia Flash Profesional 8. Yogyakarta: Andi Offset, 2006.

https://inarosita.wordpress.com/2012/08/30/the - use - of - adobe - flash - in - teaching reading-of-the-junior-high-school/ accessed on: 25th May 2015

http://syafdiichiemaizora.files.wordpress.com/2011/01/pengenalan-flash.pdf Oxford Advanced Learner's Dictionary of Current English. Oxford University Press, 2003. 